Article

\title{
Land Cover Change and Landscape Transformations (2000-2018) in the Rural Municipalities of the Upper Silesia-Zagłębie Metropolis
}

\author{
Katarzyna Pukowiec-Kurda ${ }^{1, *}$ and Hana Vavrouchová ${ }^{2}$ (1) \\ 1 Faculty of Natural Sciences, University of Silesia, Będzińska 60, 41200 Sosnowiec, Poland \\ 2 Faculty of AgriSciences, Mendel University in Brno, Zemědělská 1, 61300 Brno, Czech Republic; \\ hana.vavrouchova@mendelu.cz \\ * Correspondence: katarzyna.pukowiec@us.edu.pl
}

Received: 7 October 2020; Accepted: 24 November 2020; Published: 26 November 2020

check for updates

\begin{abstract}
Dynamic changes in the landscape have been observed in recent years. They are particularly visible in areas with a high degree of anthropopressure. An example of such areas is metropolitan regions and their immediate rural surroundings. The purpose of this article is to identify changes in land cover in the rural municipalities within metropolises and detect the processes of landscape transformation in rural areas, which are extremely sensitive to anthropopressure. The dynamics of land cover changes in the years 2000-2018 were determined using a change index (ChI), and their directions were determined using the indicator of changes in types of land cover. Corine Land Cover for level 2 groups (1.1-4.2) was used as research material, and the Upper Silesia-Zagłebie Metropolis was selected as the model area. The greatest changes in the landscape were observed in built-up areas, industrial areas, meadows and mining areas. This is due to the disappearance of the mining industry that was traditional for this region and the ongoing suburbanization process, as well as the re-industrialization of modern industry and the abandonment of arable land in rural areas.
\end{abstract}

Keywords: index of landscape changes; anthropopressure; suburbanization; Upper SilesiaZagłębie Metropolis

\section{Introduction}

According to M. Antrop [1], urbanization is a set of processes that lead to a change from a rural lifestyle to an urban one. Urbanization processes are diffusive in nature, beginning in urban centers and gradually moving to rural areas [2]. This stage is called the suburbanization phase, i.e., a further increase in the population of the agglomeration, but with greater dynamics in peripheral areas [3]. The conduct of these processes is particularly evident in areas directly neighboring large urban centers. Areas under the direct influence of urban processes emerge around large urban centers. This zone can be created by various administrative units, both small- and medium-sized cities, as well as urban-rural and rural municipalities [4]. One special case of the occurrence of the process of suburbanization is metropolitan areas, including rural municipalities, coming under urbanization pressure from neighboring cities. In that case, suburbanization is an internal process in metropolitan areas.

Over time, suburban areas become urban functions and are a symptom of the urban sprawl process. This process usually has negative environmental, landscape, economic and social consequences [5]. As for direct landscape changes, its manifestation is, inter alia, the transformation of arable land into built-up areas and fragmentation of the landscape [6,7]. Changes that indirectly affect the landscape may include disturbances in the functioning of ecosystems, which put pressure on protected areas, especially in the vicinity of large cities [8]. The ongoing processes of city expansion can cause a major 
transformation of the landscape in Europe, especially since by 2030 it is estimated that over $75 \%$ of Europe will be transformed into an urban landscape [9].

Such processes have been noted and widely tested by many researchers in different parts of Europe [10]. In Poland, they were analyzed by Gałka and Warych-Juras [11], and Zuzańska-Żyśko [12]. In Italy, Martellozzo et al. [13] modeled the expansion of a city up to 2030. In Central Europe, Vavrouchova and Toman [14] studied landscape changes in the surroundings of Brno, Bicik and Kupkova [15] in the surroundings of Prague in the Czech Republic, and Sveda [16] near Bratislava in Slovakia.

It is well-known that changing land use, and changes in individual land cover types, indicate the direction of landscape transformation and modify landscape properties. This is confirmed by A. Jjumba and S. Dragićević [17], who claim that transformation of the urban landscape is strictly tied to the process of land use change. Claessens et al. [18] considered that land use changes and landscape processes are interrelated and influenced by multiple driving factors. Long-term analyses of changes in land cover allow the processes transforming the landscape to be determined. For this reason, studies of landscape changes based on changes in land cover have been conducted for many years [19-23]. Often, the Corine Land Cover model is used as the source of land cover data. It served as research material for an analysis of landscape change in the urban area of the Ostrava and Karvina regions in Czechia [24,25] as well as the Álora region in Spain [20]. Despite numerous studies on land use change, and thus landscape change in rural areas as well [26], the topic is still scientifically attractive and constitutes a research gap due to the continuity and dynamics of these changes.

Ongoing processes of urban growth in Europe generate the need to determine the dynamics and directions of these changes. Only their correct diagnosis and balanced spatial and regional policies can reduce the negative impact of negative landscape processes such as chaotic suburbanization in Europe. Areas that are particularly vulnerable to these processes are rural areas in close proximity to large cities. Therefore, the main goal of this article is to determine changes in land cover in rural municipalities located in metropolitan areas, and detect the processes of landscape transformation with particular emphasis on their dynamics.

\section{Materials and Methods}

\subsection{Study Area}

Due to the specificity of the research topic-landscape changes in areas with high anthropopressure-rural municipalities that were part of the metropolitan region were selected as the research area. The Upper Silesia-Zagłębie Metropolis was established on 1 January 2018 and was the first metropolitan region in Poland. It is entirely located in the Ślaskie Voivodeship. It consists of 41 municipalities, both urban (28), urban-rural (1) and rural (12). It covers an area of 255,300 ha, and the population is over 2,200,000. The research was conducted in the area of rural and urban-rural municipalities, which cover 92,196 ha, which constitutes $36 \%$ of the entire area of the metropolis with a population of 124,596 in 2018, which made up almost $6 \%$ of the population of the metropolis (Bank Danych Lokalnych GUS [27]. However, rural municipalities are characterized by a high degree of population dynamics, such as a change in population over time in a given area [28], which averaged about $10 \%$ in the analyzed period 2000-2018 (Figure 1).

The researched area is located in the highlands, according to physical and geographical divisions. In terms of the binding of physical and geographical divisions in Poland [29], the area is located mainly in the Silesian Upland. Only the northern and western parts belong to the Silesian Lowland, and the south-eastern to the Oświęcim Basin.

The metropolis area is, to a large extent, the former Upper Silesian Industrial District, based on the traditional hard coal industry since the 18th century. The development of mines, smelters and towns (Figure 2) resulted in a strong landscape transformation, especially in the 20th century [30]. At the same time, highly anthropogenic areas operated in close proximity to rural and forest areas. 
For this reason, they were also subjected to dynamic landscape change processes more often than rural areas. Currently, both urban and rural areas in the metropolises are subject to strong anthropopressure. The reason for this is the restructuring of industry, the revitalization and reclamation of post-mining areas and the creation of metropolitan functions.

\subsection{Research Procedure and Data Sources}

To determine the directions of landscape changes in rural areas with strong anthropopressure, the research procedure moved from general to detailed. The analysis covered the period of the 21st century, from 2000 to 2018, as a time of major change to the landscape after economic transformation in the 1990s in the 20th century. The adopted research period guaranteed that landscape changes related to the economic transformation of the region would be captured, i.e., the transition from a traditional mining region to a metropolis in 2018. Additionally, recent years have allowed the metropolization of the landscape to be detected. In addition, carrying out an analysis up to 2018 ensures that the results are current.

The main material used for the analysis was the basic layers of data of the European Commission Corine Land Cover (CLC) [31] program from years 2000, 2006, 2012 and 2018. The data were compiled to level 2 (numbered by CLC from 1.1 to 4.2), encompassing 15 possible types of land use: urban fabric (1.1), industrial, commercial and transport units (1.2), mines (1.3), dump and construction sites (1.4), artificial non-agricultural vegetated areas (1.5), arable land (2.1), permanent crops (2.2), pastures (2.3), heterogeneous agriculture areas (2.4), forests (3.1), shrub and vegetation associations (3.2), open spaces with little or no vegetation (3.3), inland wetlands (4.1) and coastal wetlands (4.2). Of the possible 15 types of land use, there was a maximum of 10 in the municipalities of the study area. Cartographic analysis on land cover changes as well as cartographic visualization was done in the ArcGIS software. The calculations of indicators of landscape changes were made in Microsoft Excel software.

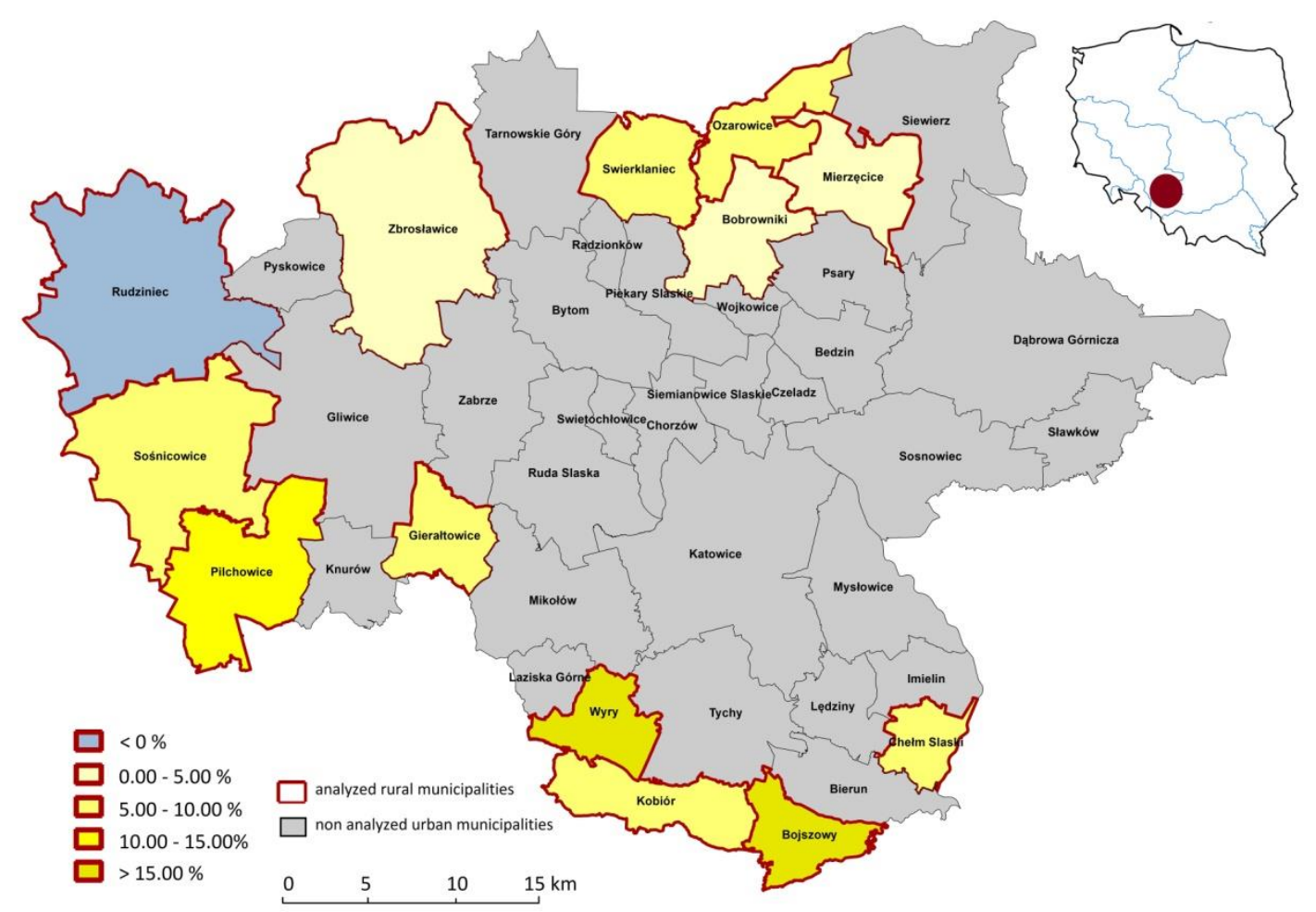

Figure 1. Population dynamics in the study area. 

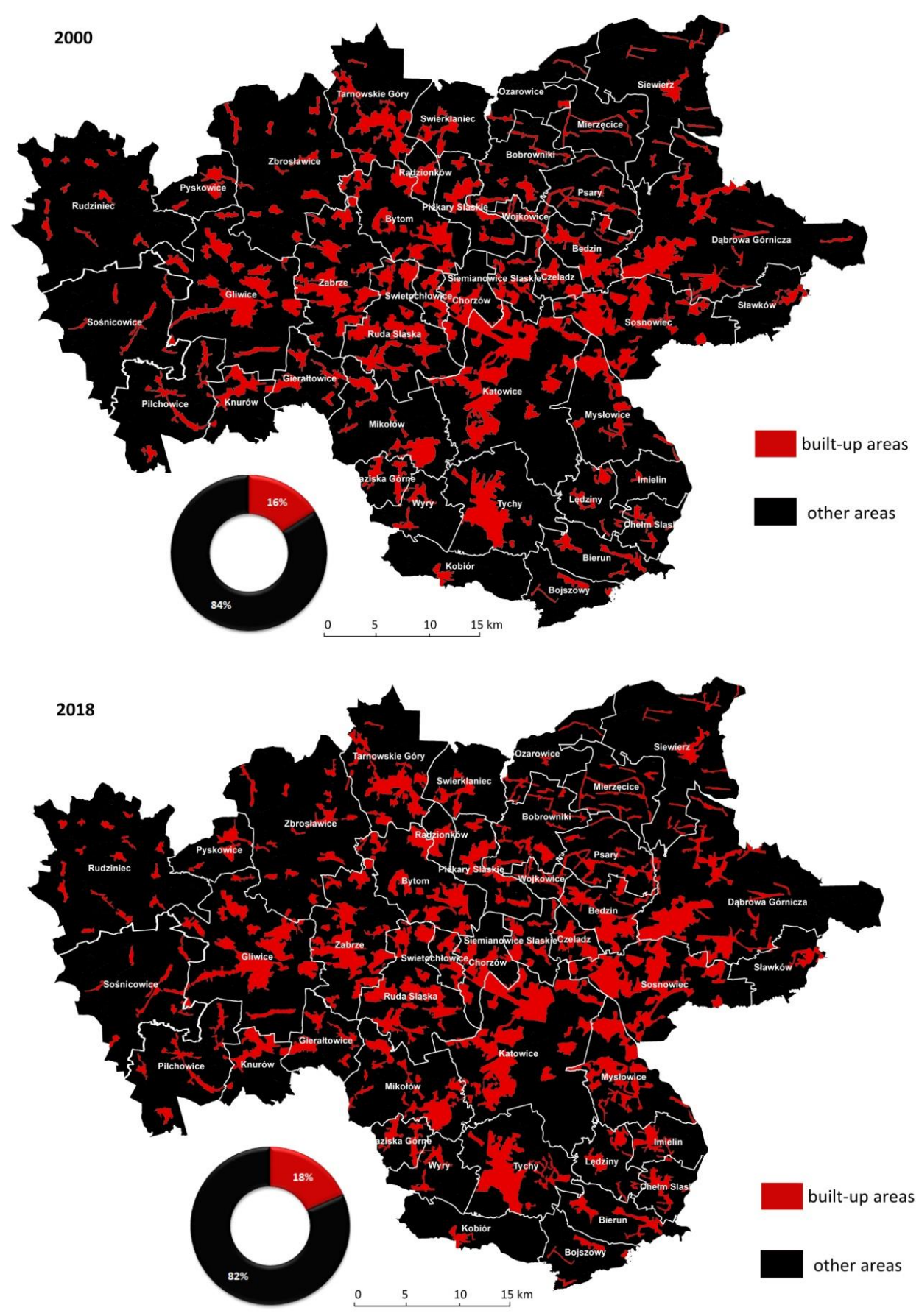

Figure 2. Built-up areas in the Upper Silesia-Zagłębie Metropolis in 2000 and 2018.

For the analysis of land cover changes, basic indexes were selected that allow the main directions of changes in landscape elements to be defined. In the first stage, an overall index of landscape change (index change) was determined in the period 2000-2018. The index change determines the ratio of the sum of the surface changes of individual coverage types to twice the unit surface. Twice the municipality area is used because the summed differences count for both increasing and decreasing values. Moreover, the area of municipalities in the analyzed period was constant. The change index indicates the general dynamics of landscape changes in a given unit. It expresses what percentage of the total area of a given unit has changed over a given period of time [15]. The higher the value of this 
indicator, the greater the change in the landscape of the study area. The index change is expressed in the following formula

$$
I C h_{(a b)}=\frac{\sum_{i=1}^{n}\left|r_{i b}-r_{i a}\right|}{2 c} \times 100
$$

where $I C h_{(a b)}$-index of change in the period between year a and $\mathrm{b}$

$n$-number of land use types

$r_{i a}$-area of type $\mathrm{x}$ in year a

$r_{i b}$-area of type $\mathrm{x}$ in year $\mathrm{b}$

$c$ - total area of municipality

Due to the fact that the index of changes provides information about the general change without specifying the types of land cover, in the second stage of the research, the index of relative change of selected land use types (IRCh) was detailed. This indicates the percentage increase or decrease of the land use type in a given period of time [16]. It also identifies emerging and disappearing land use types. The relative change of selected land use type index was calculated for all land use types from level 2 CLC. Its mathematical relationship is as follows

$$
I R C h_{(a b)}=\left(\left(\frac{r_{i b} \div c_{i b}}{r_{i a} \div c_{i a}}\right) \times 100\right)
$$

where $I R C h_{(a b)}$-index of relative change of selected land use types

$r_{i a}$-area of land use type $\mathrm{x}$ in year a

$r_{i b}$-area of land use type $\mathrm{x}$ in year $\mathrm{b}$

$c_{i a}$-total area of municipality in year a

$c_{i b}$-total area of municipality in year $\mathrm{b}$

In the last stage of the analysis, based on the index of relative change of selected land use types, it was determined which landscape transformation processes dominate in individual municipalities. They were also analyzed in terms of the intensity of the suburbanization processes, which is indicated, among other things, by the increase in the type of residential area and the decrease in arable land [1]. According to the guidelines of Antrop [1], as well as Vavruochova and Toman [14], the indicators of the suburbanization process were considered to be an increase in urban fabric (1.1) and a decrease in arable land (2.1). In addition, due to the location in the area of the former industrial district and in the area of influence of the Katowice Special Industrial Zone, the increase in industrial, commercial and transport units (1.2) was also analyzed as a suburbanization indicator.

The above three suburbanization level indicators were developed statistically by determining the median and quartiles. On the basis of their values, the intensity level of the indicators was determined, where the limit values of the intensity scale are minimum value, 1 quartile, median, 3 quartile and maximum value. Designated on the basis of statistical measurements, intervals were given the degree of intensity of the landscape-transforming phenomenon. They were described as weak or lack thereof, medium, high and very high. The occurrence of at least two of them was recognized at a high level as information on the intensive suburbanization process transforming landscape in rural municipalities.

\section{Results}

\subsection{General Index of Landscape Change}

In the entire analyzed period from 2000 to 2018, in each municipality, the index of change reached more than $3 \%$. Generally, the index of landscape changes in every municipality is still increasing (Figure 3). This can be an indication of a high dynamic of landscape processes. The largest changes in the landscape took place in the municipalities of Bobrowniki and Kobiór (ICh $>10 \%$ ) as well as in Ożarowice and Wyry (ICh > 8\%) (Figure 4). In Mierzęcice, Świerklaniec and ChełmŚląski it was 
over 5\%. In the first analyzed period from 2000 to 2006, significant changes in the landscape were recorded only in Kobiór ( $\mathrm{ICh}=4.5 \%$ ), while in 5 municipalities there were no changes in the structure of the land cover. The second examined period of 2006-2012 was a time of intensification of landscape transformation processes (Figure 4). In all the municipalities, the ICh rate was higher than $1.0 \%$. In 7 of them it reached values between $1.0 \%$ and $5.0 \%$. In Chełm Śląski, Mierzęcice, Ożarowice and Bojszowy it was between $5.0 \%$ and $8.0 \%$, while the highest values were achieved in Kobiór (ICh $=9.33 \%$ ) and Bobrowniki (ICh $=15.88 \%$ ). In the last analyzed period of 2012-2018, landscape changes were less dynamic (Figure 4). They reached the highest rate in Wyry (8.39\%). The value of 5.0\% ICh was still exceeded in Ożarowice and Chełm Ślaski, while in other municipalities, landscape changes were not significant $(\mathrm{ICh}<5.0 \%)$.

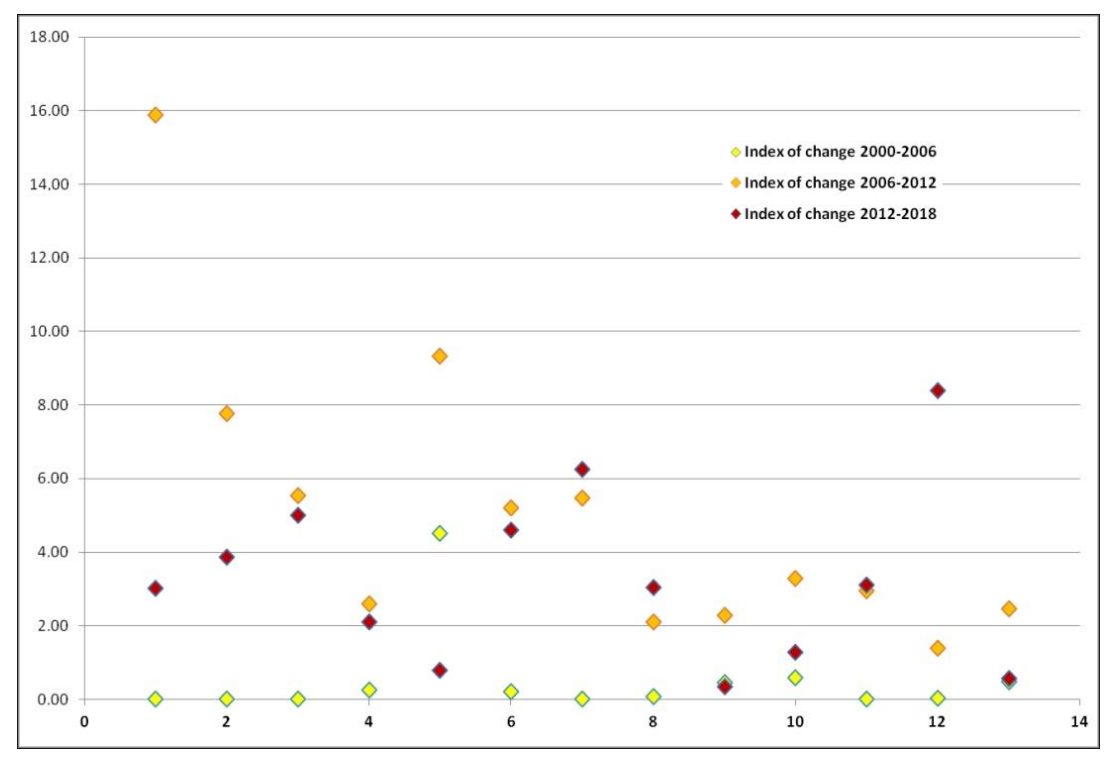

Figure 3. Dynamic of the Index of landscape change in the analyzed periods. Explanation of municipalities: 1-Bobrowniki, 2-Bojszowy, 3-ChełmŚląski, 4-Gierałtowice, 5-Kobiór, 6-Mierzęcice, 7-Ożarowice, 8-Pilchowice, 9-Rudziniec, 10-Sośnicowice, 11-Świerklaniec, 12-Wyry, 13-Zbrosławice.

\subsection{Index of Relative Change of Selected Land Use Types}

In the case of the first suburbanization indicator, which is the increase in residential areas in the period 2000-2018, it was positive in each of the analyzed municipalities (Figure 5). In 4 of them, ChełmŚląski, Ożarowice, Mierzęcice and Sośnicowice, it reached maximum values and reached a very high intensity (34.36-66.31). In Bobrowniki and Rudziniec, it reached a high value (20.25-34.36). In the remaining 7 municipalities, the intensity was medium or low. The second indicator, the decrease in arable land, is a destimulant. This means that the lower it is, the higher the intensity is. This causes the intensity scale to be inverted against traits that are stimulants. In two municipalities, Bojszowy and Mierzecice, it was positive, which means that it cannot be considered an indicator of suburbanization processes (Figure 5). In 5 municipalities, it achieved the highest intensity, i.e., -24.49 to -8 . These are Bobrowniki, Wyry, Świerklaniec, Ożarowice and ChełmŚląski. In Gierałtowice and Kobiór, it achieved a high intensity ranging from -7.99 to -5 . In the remaining 4 municipalities, it reached average or weak values. The third indicator, resulting from the specifics of the area, was the increase in the area of industrial, commercial and transport areas. In 8 units, it achieved positive values, which can be considered an indicator of suburbanization (Table 1). It reached the highest intensity in Bobrowniki, Gierałtowice and Rudziniec (Figure 5). High values were also revealed in Pilchowice, Zbrosławice and Sośnicowice. In the other two, Mierzęcice and Ożarowice, the obtained values can be assigned to the category of medium intensity. 


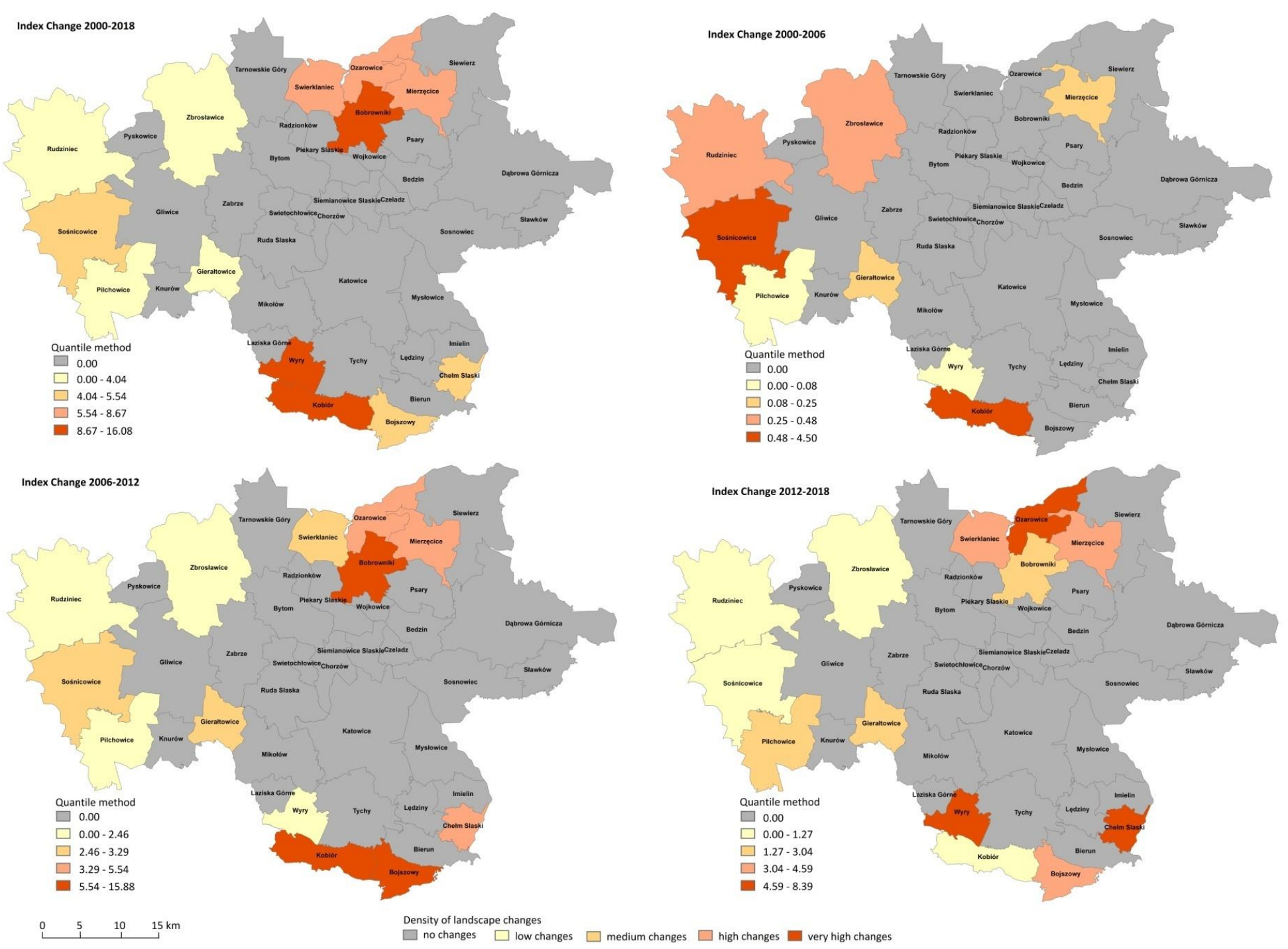

Figure 4. Values of the index of landscape change in the analyzed periods. 

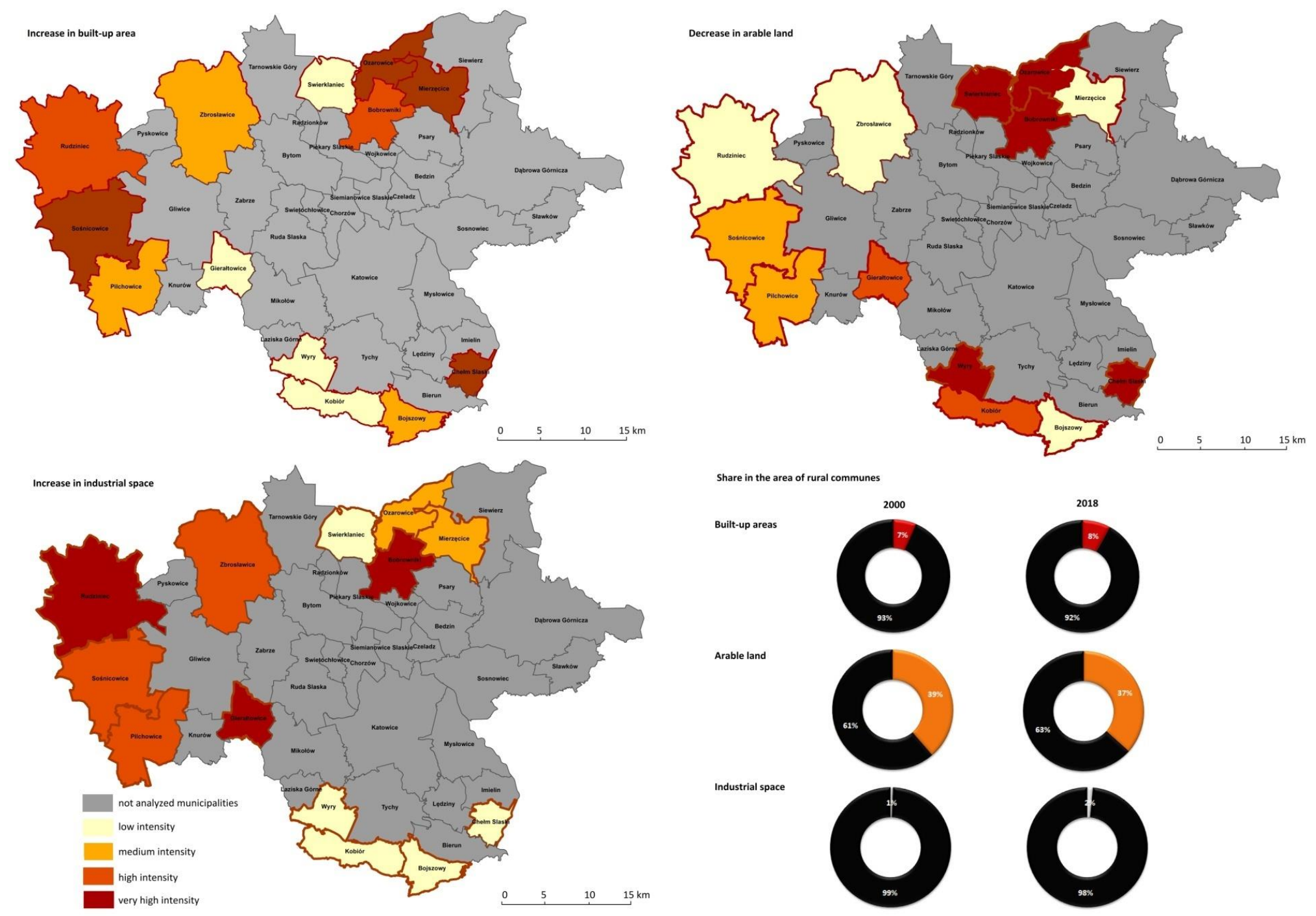

Figure 5. Intensity of landscape transformation processes in the 2000-2018 period. 
Table 1. Indicators of landscape transformation caused by suburbanization.

\begin{tabular}{|c|c|c|c|c|c|c|c|c|c|c|c|c|}
\hline \multirow{3}{*}{$\begin{array}{c}\text { Municipalitie } \\
\begin{array}{c}\text { Period from } \\
\text { to }\end{array}\end{array}$} & \multicolumn{4}{|c|}{ Build-Up Area } & \multicolumn{4}{|c|}{ Arable Land } & \multicolumn{4}{|c|}{ Industrial Area } \\
\hline & 2000 & 2006 & 2012 & 2000 & 2000 & 2006 & 2012 & 2000 & 2000 & 2006 & 2012 & 2000 \\
\hline & 2006 & 2012 & 2018 & 2018 & 2006 & 2012 & 2018 & 2018 & 2006 & 2012 & 2018 & 2018 \\
\hline Bobrowniki & 0.00 & 17.3 & 5.58 & 23.66 & 0.00 & -26.24 & 2.37 & -24.39 & 0.00 & \multicolumn{2}{|c|}{$16,842.15-2.24$} & 16,462 \\
\hline Bojszowy & 0.00 & 51.14 & -20.45 & 20.24 & 0.00 & 7.17 & -2.38 & 4.61 & 0.00 & 0.00 & 0.00 & 0.00 \\
\hline ChełmŚląski & 0.00 & 9.37 & 26.79 & 38.67 & 0.00 & 0.47 & -8.75 & -8.33 & 0.00 & -50.21 & 0.00 & -50.21 \\
\hline Gierałtowice & 0.00 & -3.56 & 4.91 & 1.17 & -0.37 & -3.35 & -1.76 & -5.41 & 110.7 & 103.7 & 0.00 & 329.12 \\
\hline Kobiór & 0.10 & 7.87 & -0.02 & 7.96 & -0.11 & -8.77 & 1.18 & -7.79 & 0.00 & 0.00 & 0.00 & 0.00 \\
\hline Mierzęcice & 0.00 & 54.13 & 7.91 & 66.31 & 0.00 & 1.46 & 0.00 & 1.46 & 0.00 & 7.09 & 20.95 & 29.53 \\
\hline Ożarowice & 0.00 & 80.65 & -25.62 & 34.36 & 0.00 & -5.15 & -3.51 & -8.47 & 0.00 & 18.12 & 53.69 & 81.55 \\
\hline Pilchowice & 0.00 & 13.64 & 3.61 & 17.74 & -0.11 & -0.98 & -2.27 & -3.34 & 100 & 0.00 & 0.00 & 100 \\
\hline Rudziniec & 0.00 & 29.33 & 3.19 & 33.46 & -0.29 & 0.15 & -0.51 & -0.61 & 52.13 & 51.78 & 0.31 & 131.61 \\
\hline Sosnicowice & -0.4 & 25.65 & 16.4 & 45.76 & -0.87 & -0.99 & -1.35 & -3.18 & 82.04 & 41.75 & -24.2 & 95.67 \\
\hline Świerklaniec & 0.00 & -0.16 & 1.35 & 0.17 & 0.00 & -1.65 & -9.84 & -11.33 & 0.00 & 0.00 & 0.00 & 0.00 \\
\hline Wyry & 0.00 & -4.97 & 7.92 & 2.56 & 0.00 & -2.65 & -16.6 & -18.84 & 0.00 & 0.00 & 0.00 & 0.00 \\
\hline Zbrosławice & 3.23 & 12.41 & 1.89 & 18.23 & -0.31 & -2.56 & 0.15 & -2.72 & 0.00 & 100 & 0.00 & 100 \\
\hline Median & & & & 20.24 & & & & -5.00 & & & & 81.55 \\
\hline Standard dev & ation & & & 19.51 & & & & 8.00 & & & & 4547.91 \\
\hline Quartile & & & & 7.96 & & & & -8.00 & & & & 0.00 \\
\hline Quartile & & & & 34.36 & & & & -3.00 & & & & 100.00 \\
\hline
\end{tabular}

Note: yellow-low intensivity between the lowest value and quartile 1 ; orange-medium intensivity between quartile 1 and the median; red-high intensivity between the median and quartile 3; dark red-very high intensivity between quartile 3 and the maximum value.

\subsection{Intensity of Individual Spatial Landscape Transformation Indicators}

By analyzing the intensity of individual spatial landscape transformation indicators, the intensity of suburbanization in the rural municipalities of the metropolis was determined. The most dynamic spatial changes, indicating a progressing suburbanization process, occurred in Bobrowniki. Slightly smaller changes in the intensity of space could be seen in ChełmŚląski, Gierałtowice, Ożarowice, Rudziniec and Sośnicowice (Figure 6). In 6 municipalities, the intensity of suburbanization expressed by spatial changes was at an average level: Kobiór, Mierzęcice, Pilchowice, Świerklaniec, Wyry and Zbrosławice (Figures 6 and 7). In Bojszowy, suburbanization processes were the weakest. 


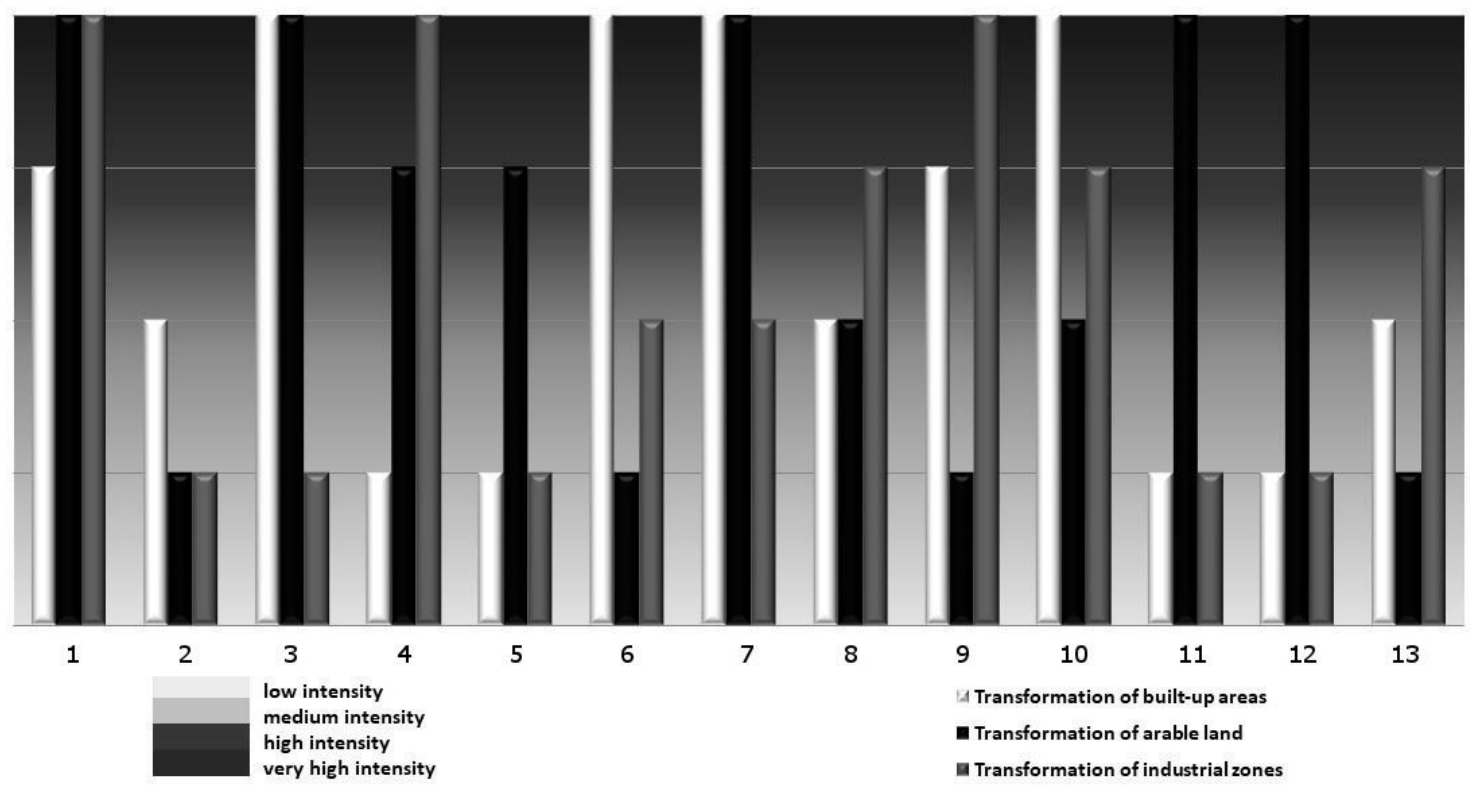

Figure 6. Intensity of landscape transformation in rural municipalities in the Upper Sielsia-Zagłębie Metropolis in the period 2000-2018. The intensity of the background color indicates the degree of landscape change. Explanation of municipalities: 1-Bobrowniki, 2-Bojszowy, 3-ChełmŚląski, 4-Gierałtowice, 5-Kobiór, 6-Mierzęcice, 7-Ożarowice, 8-Pilchowice, 9-Rudziniec, 10—Sośnicowice, 11-Świerklaniec, 12-Wyry, 13-Zbrosławice.

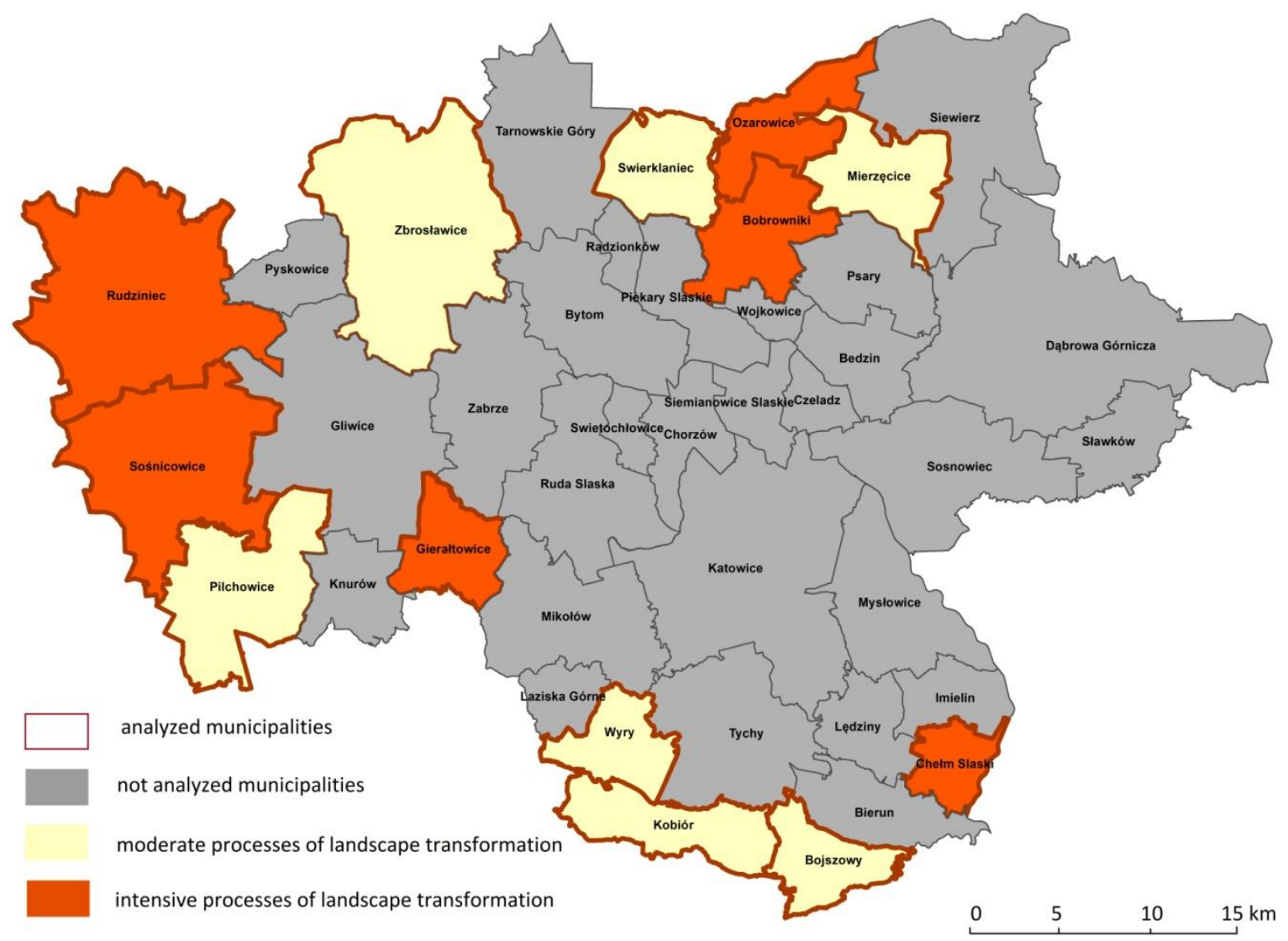

Figure 7. Rural municipalities with the biggest landscape transformation in the period 2000-2018. 


\section{Discussion}

\subsection{Inner Suburbanization as the Main Process of Transformation Landscape}

The landscape of anthropogenically changed areas is subject to strong transformations. This is confirmed by the results of landscape metrics enabling the assessment of its changes, e.g., the index of landscape change. In the investigated area, in each successively analyzed period this index was larger than in the previous one, which proves the great dynamics of landscape transformation processes. Therefore, to be able to forecast landscape changes well, we need to know their character and driving forces. There are many reasons for these changes, but in the metropolis area the most important of them is suburbanization processes. The typical symptoms of the suburbanization process are an increase in built-up areas and a decrease in arable land. Attention has been paid to this by many researchers, including Vavrochova and Toman [14], Antrop [1], Mosammam et al. in Qom city [32] and Hualou et al. in Chinese cities [33]. The above research carried out in rural areas of the Upper Silesia-Zagłebie Metropolis also confirmed this, but with some differences.

According to Krzysztofik et al. [34], the analyzed area is not subject to the classic suburbanization process observed in other Polish agglomerations or in the neighboring and similar Ostrava Coal Region in Czechia [35]. In the analyzed area, suburbanization occurs within the metropolis, i.e., from its core cities to the neighboring rural or urban municipalities within it. This phenomenon is known as inner suburbanization [36] and is possible because of the area of $1000 \mathrm{~km}^{2}$ that the metropolis occupies. Due to these processes, inner suburbanization takes place over a huge area and is unevenly distributed in the space. For this reason, in the analyzed area, it is difficult to delimit typical suburban zones [34]. Rather, they appear as clustered zones of new settlements in single municipalities. For this reason, landscape transformations are also subject to different processes and different dynamics. They depend on the phase of development of metropolitan functions, as well as on regional conditions.

Rural areas of the Upper Silesia-Zagłebie Metropolis have a peripheral location towards the core of the metropolis and municipalities. They are, therefore, a buffer between the metropolitan zone and the external areas (Figure 8a). Increasing the acreage of built-up areas in these areas indicates the phenomenon of urban sprawl, i.e., expanding urban and suburban fabric but with local specifications. The phenomenon of suburbanization has already been diagnosed in the area of the Katowice agglomeration $[5,12,34,36]$. The main driving force for the urban sprawl process is the structure of the communication network, in particular the location of highways and expressways [37]. This is evidenced by the intensity of the urban sprawl process in municipalities along the A4 motorway (Sośnicowice) and the A1 motorway (Ożarowice, Bobrowniki) (Figure 8b). Uncontrolled development of the urban fabric, especially in peripheral areas (rural, agricultural), can have negative consequences. Urbanization replacing agricultural land is a global problem, which is emphasized by Martelozzo et al. [38], as well as Pandey and Seto [39]. They also emphasize that the areas most sensitive to change are those in the vicinity of large cities. This is associated with lower transport costs and travel times to work [13]. 


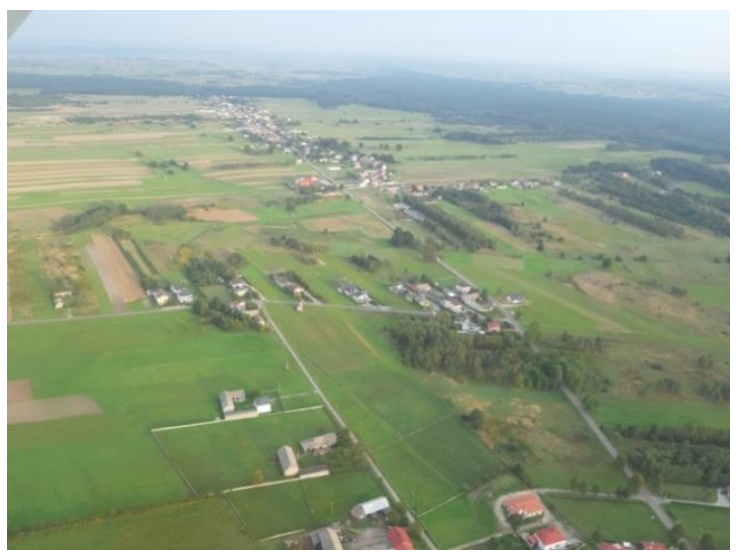

(a)

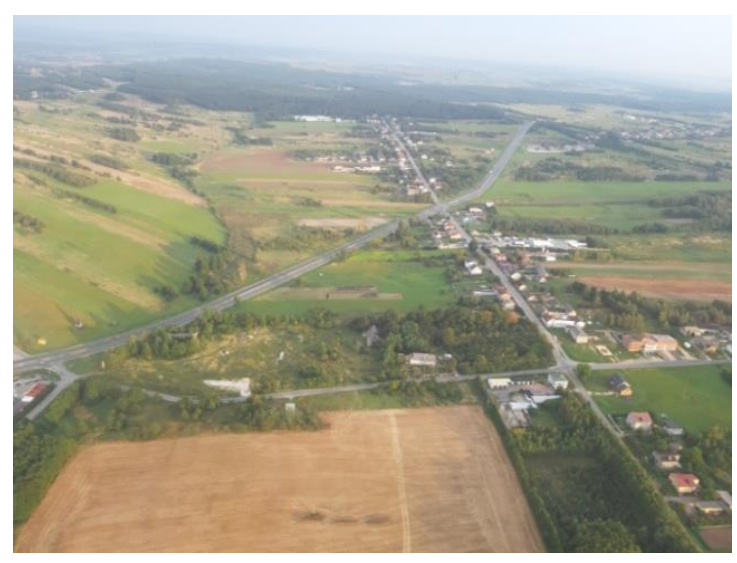

(b)

Figure 8. Rural areas in Ożarowice municipality with visible abandonment (a,b), new houses_urban sprawl (a) and landscape fragmentation by expressway (b).

\subsection{Abandonment and Re-Industralization as a Complementary Processes of Landscape Transformation}

The rise of buildings in earlier rural areas has negative effects both on the ecological system, by loss of habitat, degradation of soil cover and changes in water conditions, and on agriculture, e.g., through a decrease in agricultural production or the fragmentation of agriculture land [32]. In addition, some arable fields undergo secondary succession, as a result of which, in subsequent research periods, it is shown as wasteland and areas with dispersed vegetation or forests. This is connected with the process of abandonment of arable lands, which is popular in Central Europe [40]. This is confirmed by the results obtained in Italy [13] and in similar agglomerations of the Ostrava Coal Region in Czechia [41]. This phenomenon is evident in the area of the northern municipalities of the studied metropolis, Bobrowniki and Ożarowice, which is confirmed by the obtained test results (Figure 8a,b). Abandonment is associated with the disappearance of traditional agriculture. The landscape manifests itself in the transformation of arable fields into wasteland, and eventually into forests.

Due to their location in the area of the former industrial district, agricultural areas can also be transferred into emerging industrial zones. This is a specific process for the investigated region-the increased area of industrial zones. In the analyzed area, the traditional mining industry is closing (de-industrialization) while, simultaneously, the emergence of modern plants of other types of industry, e.g., automotive, machinery (re-industrialization), is occurring. This process was described by Krzysztofik et al. [42] and, in the investigated region, known as trans-industrialization. This is confirmed by changes in the landscape that on the one hand indicate the disappearance of mining areas, and on the other hand the growth of industrial areas. This is mainly due to its location in the former industrial district, where one of the largest industrial zones in Poland has developed based on the existing industrial and communication infrastructure and social capital. The Katowice Special Economic Zone and its subzones were also located in rural municipalities, in the vicinity of the largest cities of the metropolis, e.g., Gliwice, Katowice and Tychy. A similar phenomenon of the industrial transformation of the landscape has also been observed in the coal area of Western Slovakia [43]. Popelkova and Mulkova [41] also pay attention to the specifics of mining landscapes in the Ostrava Coal Region and their further development and possible reclamation.

Changes in land cover in rural municipalities as well as landscape transformation processes are presented in Figure 9. 


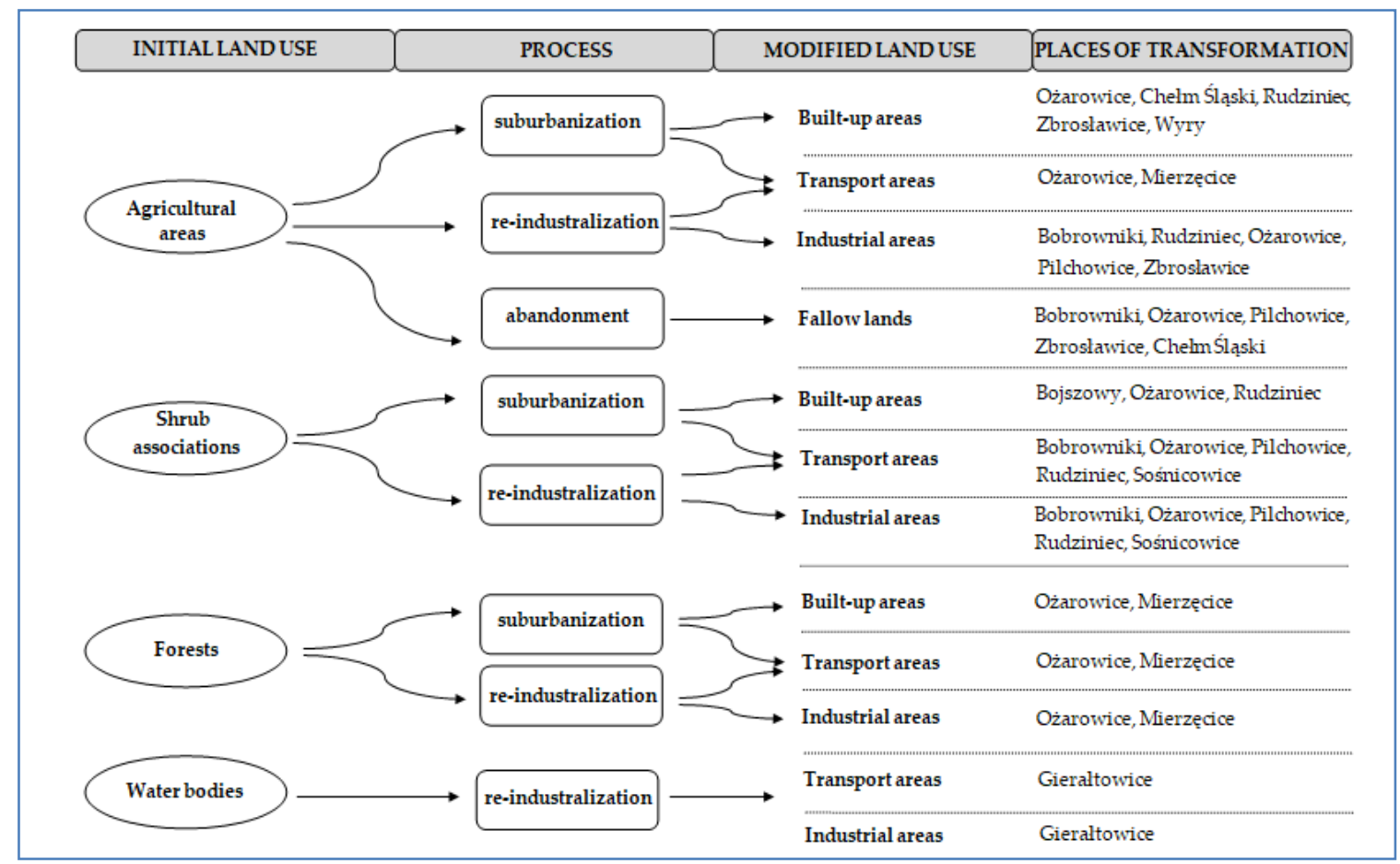

Figure 9. Theoretical model of landscape transformation in the analyzed area.

\subsection{Usefulness of the Data Sources and Research Procedure}

There are many methods for assessing the degree of landscape transformation, including landscape metrics. Many researchers have used a variety of metrics to assess landscape changes [44], both simple indicators and more complex formulas [45-47]. Basic indicators were used to determine landscape changes based on land cover changes. The landscape change index allows an overall assessment of the percentage change. However, supplemented with an indicator of relative changes in the landscape in relation to the types of land cover, it allows the identification of the main processes transforming the landscape. The applied methodology, despite the fact that it uses simple indicators of landscape changes, allowed the authors to achieve the main goal of the research, which was to identify changes in land cover in the rural municipalities within a metropolis. A deeper analysis of the reasons for these changes provides opportunities for the drawing of conclusions in planning and space management documents. The results obtained can be an indication of the direction in which landscape changes take place, which types of coverage are expanding and which are decreasing or completely disappearing. A valuable supplement to the obtained results could be the analysis of planning documents of municipalities and their spatial policy. This aspect is a broader research topic than the article and will continue in future works.

As well as using landscape metrics taken from many researchers as a database, the CLC was also used [23,48-50]. Its main advantage is its timeliness and its accessibility to the whole of Europe, which allows for the comparison of research results. Unfortunately, this model has limitations, mainly due to the scale of its development and the detection of areas with a suitable surface (minimum mapping is 5 ha) [50]. Nevertheless, it allows the use of the model to analyze land changes on a regional scale, which would be impossible on a planning (cadastral) scale. Therefore, it is still the most frequently used source for the analysis of land changes and, according to Cieślak et al. [49], it is an appropriate tool for the analysis of urbanization processes. 


\section{Conclusions}

In the investigated area, the processes of the transformed landscape have been successfully managed. They are suburbanization with the phenomena of urban sprawl, de-industrialization of the traditional mining industry and re-industrialization of modern industry, as well as abandonment of arable land. The investigated metropolises have shown that rural areas are subject to the urban sprawl process. However, this does not occur in a classical way, transforming rural zones into suburban zones, but creating clusters of new residential buildings, sometimes in the middle of arable fields (as in Siewierz). Areas of arable fields have been drastically reduced due to the expansion of cities but also due to industrial zones as an effect of the re-industrialization process. A common process in rural areas is also the abandonment of arable land, which becomes changed into wasteland. If the changes continue in the same direction in the future, rural zones will be built-up with housing estates, but also changed into industrial areas. This may be related to the density of road and rail infrastructure, as well as the emergence of new functional zones in rural areas, such as shopping centers and logistics centers that will serve the industry. Over time, rural landscapes will transform into multifunctional suburban areas, and these will become urban landscapes.

Forecasting transformations is necessary for the sustainable space management of the entire metropolis, both in urban and rural areas. This allows a limiting of the negative impacts of dynamic and chaotic changes in the landscape to which the metropolis is currently subject, in particular its rural areas. Metropolitan rural municipalities are extremely important because they are a buffer zone with ecological and agricultural functions for urbanized areas. At the same time, they are areas that are increasingly beginning to take over urban functions, not only residential but also industrial. Unplanned and careless introduction of these new functions can lead to both the environmental and social degradation of these areas. To prevent this, landscape transformation processes in areas with such dynamics should be constantly monitored. Analysis of these changes in the long term will allow a modeling of landscape transformation in the future. This is important because the dynamics of landscape changes in the Upper Silesia-Zagłębie Metropolis are very high.

Author Contributions: Conceptualization, K.P.-K.; methodology, K.P.-K. and H.V.; software, K.P.-K.; validation, K.P.-K.; formal analysis, K.P.-K.; investigation, K.P.-K.; resources, K.P.-K.; data curation, K.P.-K.; writing-original draft preparation, K.P.-K.; writing-review and editing, K.P.-K.; visualization, K.P.-K.; supervision, K.P.-K. Both authors have read and agreed to the published version of the manuscript.

Funding: This research received no external funding.

Conflicts of Interest: The authors declare no conflict of interest.

\section{References}

1. Antrop, M. Landscape change and the urbanization process in Europe. Landsc. Urban Plan. 2004, 67, 9-26. [CrossRef]

2. Bryant, C.; Russwurm, L.; McLellan, A. The City's Countryside: Land and Its Management in the Rural Urban Fringe; Longman: London, UK, 1982.

3. Champion, T. Urbanization, suburbanisation, counterurbanisation and reurbanisation. In Handbook of Urban Studies; Paddison, R., Ed.; Sage: London, UK, 2001; pp. 143-161.

4. Maik, W. Podstawy Geografii Miast (Basics of City Geography); Wydawnictwo Uniwersytetu Mikołaja Kopernika: Toruń, Poland, 1997.

5. Pukowiec-Kurda, K.; Myga-Piątek, U.; Rahmonov, O. The landscape profile method as a new tool for sustainable urban planning. J. Environ. Plan. Manag. 2019, 62, 2548-2566. [CrossRef]

6. Ewing, R.H. Characteristics, causes, and effects of sprawl: A literature review. In Urban Ecology; Marzluff, J.M., Shulenberger, E., Endlicher, W., Alberti, M., Bradley, G., Ryan, C., Simon, U., ZumBrunnen, C., Eds.; Springer: Boston, MA, USA, 2008; Volume 3, pp. 519-535. [CrossRef]

7. Travisi, C.M.; Camagni, R.; Nijkamp, P. Impacts of urban sprawl and commut-ing: A modelling study for Italy. J. Transp. Geogr. 2010, 18, 382-392. [CrossRef] 
8. Güneralp, B.; Seto, K.C. Futures of global urban expansion: Uncertainties andimplications for biodiversity conservation. Environ. Res. Lett. 2013, 8. [CrossRef]

9. Seto, K.C.; Güneralp, B.; Hutyra, L.R. Global forecasts of urban expan-sion to 2030 and direct impacts on biodiversity and carbon pools. Proc. Natl. Acad. Sci. USA 2012, 109, 16083-16088. [CrossRef] [PubMed]

10. Hennig, E.I.; Schwick, C.; Soukup, T.; Orlitova, E.; Kienast, F.; Jaeger, J.A.G. Multi-Scale Analysis of Urban Sprawl in Europe: Toward a European De-Sprawling Strategy. Land Use Policy 2015, 49, 483-498. [CrossRef]

11. Gałka, J.; Warych-Juras, A. Suburbanization and migration in Polish metropolitan areas during political transition. Acta Geogr. Geogr. 2018, 52, 63-72. [CrossRef]

12. Zuzańska-Żyśko, E. Procesymetropolizacji. Teoria Ipraktyka; PWN: Warszawa, Poland, 2016.

13. Martellozzo, F.; Amato, F.; Murgante, B.; Clarke, K.C. Modelling the impact of urban growth on agriculture and natural land in Italy to 2030. Appl. Geogr. 2018, 91, 156-167. [CrossRef]

14. Vavrouchová, H.; Toman, F. Landscape dynamics in the Brno's surrounding between 2001 and 2011. Acta Univ. Agric. Silvic. 2003, 61, 1451-1457. [CrossRef]

15. Bičík, I.; Kupková, L. Landuse development in the Czech Republic and possibilities of generalization and modelling. In Modelling Natural Environment and Society; Dostál, P., Ed.; Charles University in Prague: Prague, Czech Republic, 2007; pp. 179-203.

16. Šveda, M. Zmenyvovyužitízemevofunkcnommestskomregióne Bratislava. Acta Geogr. Univ. Comen. 2010, 54, 137-155.

17. Jjumba, A.; Dragićević, S. High Resolution Urban Land-use Change Modeling: Agent iCity Approach. Appl. Spat. Anal. 2012, 5, 291-315. [CrossRef]

18. Claessens, L.; Schoorl, J.M.; Verburg, P.H.; Geraedts, L.; Veldkamp, A. Modelling interactions and feedback mechanisms between land use change and landscape processes. Agric. Ecosyst. Environ. 2009, 129, 157-170. [CrossRef]

19. Gibson, C.C.; Ostrom, E.; Ahn, T.K. The concept of scale and the human dimensions of global change: A survey. Ecol. Econ. 2000, 32, 217-239. [CrossRef]

20. Schoorl, J.M.; Veldkamp, A. Linking land use and landscape process modelling: A case study for the Álora region (south Spain). Agric. Ecosyst. Environ. 2001, 85, 281-292. [CrossRef]

21. Goetz, S.J.; Jantz, C.A.; Prince, S.D.; Smith, A.J.; Varlyguin, D.; Wright, R. Integrated analysis of ecosystem interactions with land use change: The Chesapeake Bay watershed. In Ecosystem Interactions with Land Use Change; Asner, G.P., Houghton, R.A., Eds.; American Geophysical Union: Washington, DC, USA, 2004; Volume 13, pp. 212-225.

22. Couclelis, H. "Where has the future gone?" Rethinking the role of integrated land-use models in spatial planning. Environ. Plan. A 2005, 37, 1353-1371. [CrossRef]

23. Krajewski, P.; Solecka, I.; Mrozik, K. Experience in Identification of Landscape Background for Rural Landscapes in the Suburban Area of Wrocław. Diss. Cult. Landsc. Comm. 2017, 37, 117-125.

24. Popelková, R.; Mulková, M. Landscape Changes Mapping: Central Part of Ostrava-Karviná Mining District. J. Maps 2011, 363-375. [CrossRef]

25. Mulková, M.; Popelka, P.; Popelková, R. Landscape Changes in the Central Part of The Karviná Region from the First Half of the 19th Century to the Beginning of the 21st Century. Ekológia (Bratislava) 2012, 31, 75-91. [CrossRef]

26. Verburg, P.H.; Schulp, C.J.E.; Witte, N.; Veldkamp, A. Downscaling of land use change scenarios to assess the dynamics of European landscapes. Agric. Ecosyst. Environ. 2006, 114, 39-56. [CrossRef]

27. Bank Danych Lokalnych Głównego Urzędu Statystycznego. Available online: https://bdl.stat.gov.pl/BDL/start (accessed on 3 February 2020).

28. Runge, A.; Runge, J. Słownikpojęć z Geografiispoleczno-Ekonomicznej (Dictionary of Terms in Socio-Economic Geography); Videograf Edukacja: Chorzów, Poland, 2008; p. 382.

29. Kondracki, J. Geografia Regionalna Polski (Reional Geography of Poland); PWN: Warszawa, Poland, 1977.

30. Dulias, R. The Impact of Mining on the Landscape. A Study of the Upper Silesian Coal Basin in Poland. Environmental Science and Engineering; Springer International Publishing: Cham, Switzerland, 2016; p. 209. [CrossRef]

31. European Environment Agency (EEA). Corine Land Cover (CLC). Available online: https://www.eea.europa. eu/publications/COR0-landcover (accessed on 3 February 2020). 
32. Mosammam, H.M.; Nia, J.T.; Khani, H.; Teymouri, A.; Kazemi, M. Monitoring Land Use Change and Measuring Urban Sprawl Based on Its Spatial Forms. Egypt. J. Remote Sens. Space Sci. 2017, 20, 103-116. [CrossRef]

33. Hualou, L.; Gerhard, K.H.; Xiubin, L.; Ming, Z. Socio-economic development and land-use change: Analysis of rural housing land transition in the Transect of the Yangtse River, China. Land Use Policy 2007, 24, 141-153. [CrossRef]

34. Krzysztofik, R.; Kantor-Pietraga, I.; Runge, A.; Spórna, T. Is the suburbanisation stage always important in the transformation of large urban agglomerations? The case of the Katowice Conurbation. Geogr. Pol. 2017, 90,71-85. [CrossRef]

35. Rumpel, P.; Slach, O. Governance of Shrinkage of the City of Ostrava; European Science and Art Publishing: Prague, Czech Republic, 2012.

36. Spórna, T.; Krzysztofik, R. 'Inner' suburbanization-Background of the phenomenon in a polycentric, post-socialist and post-industrial region. Example from the Katowice conurbation, Poland. Cities 2020, 104. [CrossRef]

37. Gomez-Antonio, M.; Hortas-Rico, M.; Li, L. The Causes of Urban Sprawl in Spanish Urban Areas: A Spatial Approach. Spat. Econ. Anal. 2014, 11, 219-247. [CrossRef]

38. Martellozzo, F.; Ramankutty, N.; Hall, R.J.; Price, D.T.; Purdy, B.; Friedl, M.A. Urbanization and the loss of prime farmland: A case study in the Calgary-Edmonton corridor of Alberta. Reg. Environ. Chang. 2014, 15, 881-893. [CrossRef]

39. Pandey, B.; Seto, K.C. Urbanization and agricultural land loss in India: Comparing satellite estimates with census data. J. Environ. Manag. 2015, 148, 53-66. [CrossRef]

40. Janus, J.; Bożek, P. Land abandonment in Poland after the collapse of socialism: Over a quarter of a century of increasing tree cover on agricultural land. Ecol. Eng. 2019, 138, 106-117. [CrossRef]

41. Popelková, R.; Mulková, M. The Mining Landscape of the Ostrava-Karviná Coalfield: Processes of Landscape Change from the 1930s to the Beginning of the 21st Century. Appl. Geogr. 2018, 90, 28-43. [CrossRef]

42. Krzysztofik, R.; Tkocz, M.; Spórna, T.; Kantor-Pietraga, I. Some dilemmas of post-industrialism in a region of traditional industry: The case of the Katowice conurbation, Poland. Morav. Geogr. Rep. 2016, 24, $42-54$. [CrossRef]

43. Vojtek, M.; Vojteková, D. Mapping and assessement of land changes in coal mining area: A case study from Slovakia. In Proceedings of the 5th International Multidisciplinary Scientific Conference on Social Scienes and Arts. Conference Proceedings, Urban Planning Architecture Design, Vienna, Austria, 19-21 March 2018; STEF92 Technology Ltd.: Sofia, Bulgaria, 2018; Volume 5, pp. 439-446. [CrossRef]

44. Krajewski, P. Assessing Change in a High-Value Landscape: Case Study of the Municipality of Sobotka, Poland. Pol. J. Environ. Stud. 2017, 26, 2603-2610. [CrossRef]

45. Verburg, P.H.; Veldkamp, W.S.A.; Espaldon, R.L.V.; Mastura, S.S.A. Modeling the Spatial Dynamics of Regional Land Use: The CLUE-S Model. Environ. Manag. 2002, 30, 391-405. [CrossRef] [PubMed]

46. Yu, X.J.; Ng, C.N. Spatial and temporal dynamics of urban sprawl along two urban-rural transects: A case study of Guangzhou, China. Landsc. Urban Plan. 2007, 79, 96-109. [CrossRef]

47. Van Rompaey, A.; Krasa, J.; Dostal, T. Modelling the impact of land cover changes in the Czech Republic on sediment delivery. Land Use Policy 2007, 24, 576-583. [CrossRef]

48. Benito, P.R.; Cuevas, J.A.; Bravo de la Parra, R.; Prieto, F.; Garcia del Barrio, J.M.; Zavala, M.A. Land use change in a Mediterranean metropolitan region and its periphery: Assessemenet of conservation policies through CLC and Markov model. For. Syst. 2010, 19, 315-328.

49. Cieślak, I.; Biłozor, A.; Szuniewicz, K. The Use of the CORINE Land Cover (CLC) Database for Analyzing Urban Sprawl. Remote Sens. 2020, 12, 282. [CrossRef]

50. Śleszyński, P.; Gibas, P.; Sudra, P. The Problem of Mismatch between the CORINE Land Cover Data Classification and the Development of Settlement in Poland. Remote Sens. 2020, 12, 2253. [CrossRef]

Publisher's Note: MDPI stays neutral with regard to jurisdictional claims in published maps and institutional affiliations. 